\title{
Approach to Reduce Throughput Time in Grinding of Gundrills
}

\author{
Vishwas Mahesh $^{1 *}$, Sudheendra Shastry ${ }^{1}$, Vasudev Murthy², Vijay Kumar ${ }^{1}$, Vinyas Mahesh ${ }^{3,4}$ \\ ${ }^{1}$ Department of Industrial Engineering and Management, Siddaganga Institute of Technology, Tumakuru 572102, India \\ ${ }^{2}$ Kennametal India Limited, Bengaluru 560073, India \\ ${ }^{3}$ Department of Mechanical Engineering, Nitte Meenakshi Institute of Technology, Yelahanka, Bengaluru 560064, India \\ ${ }^{4}$ Department of Aerospace Engineering, Indian Institute of Science, Bengaluru 560012, India
}

Corresponding Author Email: vishwasm@sit.ac.in

https://doi.org/10.18280/jesa.520204

Received: 6 January 2019

Accepted: 23 March 2019

\section{Keywords:}

gundrill, grinding, throughput time, cycle time, ARENA

\begin{abstract}
In modern industries automated machines are considered as one of the most important constituent in improving productivity. Gundrills are special cutting tools used for deep-hole drilling to achieve a depth to diameter ratio ranging up to 300:1. Gundrill production is largely dependent on manual operations owing to the manufacturing complexities. The total throughput time in gundrill manufacturing is significantly affected by the manual grinding process. This paper presents a study on the various grinding operations and identifies bottlenecks during gundrill production. Simulation is done in ARENA by Rockwell Automation Inc. for the manual process as well as for the automation required for the required for reduction in cycle time. Non-parametric tests are conducted for validating the ARENA model. Conclusions are drawn to automate the production aimed at reducing the cycle time while improving quality and EHS (Environment, Health, Safety) practice by eliminating tedious and repetitive operations. The present work serves as a benchmark approach for any manufacturing engineer intended to reduce the throughput time of any components.
\end{abstract}

\section{INTRODUCTION}

Gundrills are the straight fluted drill which allows cutting fluids (either compressed or suitable liquid) to be injected through drill's hollow body to the cutting face. They are used for a deep drilling- a depth to diameter ratio of 300:1 is possible. A standard gundrill has a single effective cutting edge. Guide pads burnish the hole while drilling, allowing the hole to maintain straightness. The result of this burnishing activity is a very round hole with a precision diameter. Gundrill was initially developed for drilling gun barrels.

The gundrill is fabricated with a drill head section with carbide cutting blade. The head section is brazed to a heat treated tube (flute) section then fitted and brazed to hardened ground steel driver. The driver or shank, the single flute gundrill is provided with a driver for holding the tool in the machine spindle. A design methodology to sharpen the gundrill was developed by [1]. There are several types of carbide tip based on their coolant holes and guide pads. Tungsten carbide is one of the material used and their grinding method was discussed in the study carried out by [2]. The force system and performance of the welding carbide gun drill to cut AISI 1045 steel was discussed by [3]. Gun drilling in Inconel 718 for considering various parameters was discussed by [4]. Influence of preparation of surfaces on the tool life of the twist drills was studied by [5].

A cycle time of a job is the time required for the job to go through the factory. Reducing the cycle time is very important for the following factors. 1. Large cycle time means it is difficult to convert the opportunity cost into profits in the short term. 2. Results in accumulation of jobs resulting in bottleneck [6]. Throughput time is the amount of time required for a product to pass through a manufacturing process, thereby being converted from raw materials into finished goods. It covers the entire time from when it first enters manufacturing until it exits manufacturing which includes processing time, inspection time, move time and queue time. An algorithm to predict the throughput time was proposed by [7]. Calculating the throughput time of a production run is a complicated task [8-9]. A note on understanding the cycle time by [10] clearly showed the difference between cycle time, process time and throughput time. Process time is the period during which work is performed on job itself [11]. Manufacturing throughput time could be daunting task due to many factors that influence it and their complex interactions. Some guidelines to reduce throughput time are presented earlier like production and transfer batch size reductions offer the largest potential for MTTP (Manufacturing throughput time per part). If the plant has a job shop/ functional layout in place, significant reductions in batch size may require conversion to manufacturing cells which reduce move time, processing time, process variability and arrival variability further reducing MTTP [12]. Cellular manufacturing system is another method that helps in reducing throughput time [13]. An approach to reduce throughput time during the product design has been proposed by [14]. Design for production determines how new product design affects the performance which includes design guidelines, capacity analysis, and estimating throughput time [15].

This paper presents a study on the various grinding operations and identifies bottlenecks during gundrill production. Simulation is done in ARENA by Rockwell Automation Inc. for the manual process as well as for the automation required for the required for reduction in cycle 
time. Non-parametric tests are conducted for validating the ARENA model.

\section{METHODOLOGY}

In the conventional method of manufacturing gundrill several processes have to be followed which are shown below in Figure 1.

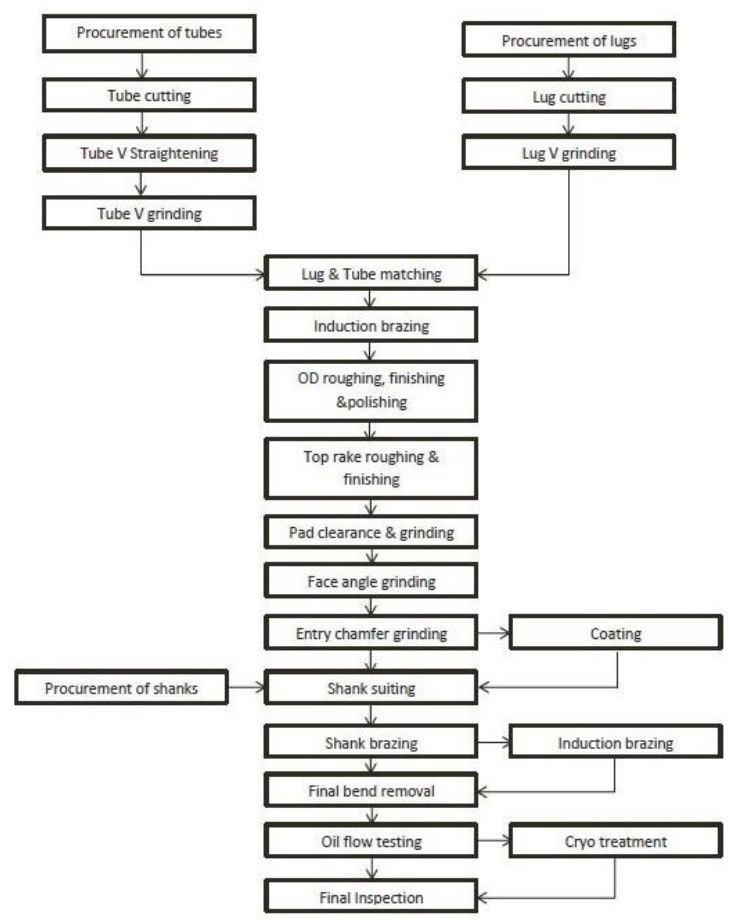

Figure 1. Flow chart of the manufacturing operation

The operations for the end product are carried out in the same procedure for every single gundrill. In manufacturing of gundrill the major operation involved is grinding and the cycle time taken for these grinding processes are high compared to other processes. At first study of gundrill classifications and specifications are done followed by understanding each operations involved in it and visualizing the process which is taking more cycle time which is responsible for the total throughput time. The factors affecting the cycle timings of grinding operations are explained through fish bone diagram shown in below Figure 2 .

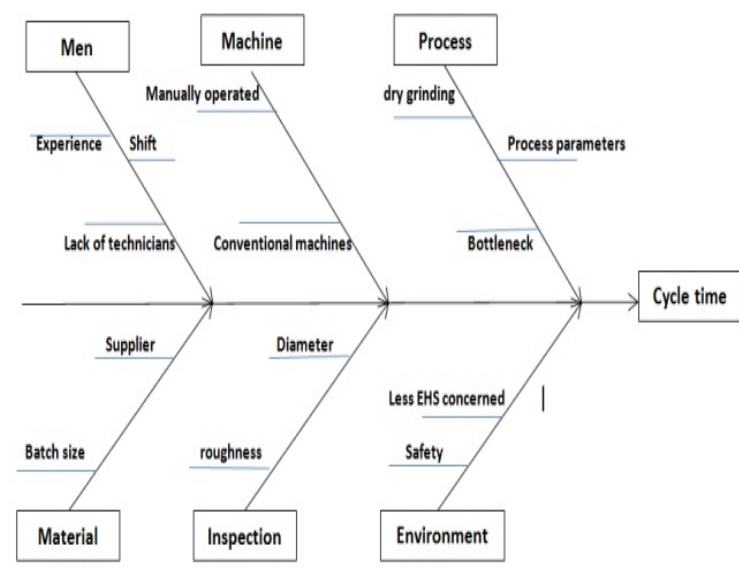

Figure 2. Fish-bone diagram for analyzing cycle time
It can be explained in the fishbone diagram that major parameters concerned with the reduction in cycle time. Here in the current situation issues only with men, machine, inspection and process are more visualized in the increase of throughput time for grinding process. For the analysis of the cycle time, processing times of different diameter single flute gundrill is noted. In this move time, inspection time and queue time are negligible because time taken by these is much less compared to the processing time of the job. So reducing the processing time of the operations which are creating bottleneck will reduce a major amount of total throughput time which will result increase in the productivity.

\section{EXPERIMENTATION AND ANALYSIS}

The above problem is observed in manufacturing of gundrills in Kennametal India Ltd., due to high cycle times taken in the grinding processes couldn't reach the targets in the specified period of time and the remaining components are piled up for the next installment. Table 1 show the timings noted for gundrills of diameter $8 \mathrm{~mm}$ and $11.15 \mathrm{~mm}$.

Table 1. Processing time for operations

\begin{tabular}{|c|c|c|c|c|c|}
\hline \multirow{2}{*}{$\begin{array}{l}\text { Sl. } \\
\text { No. }\end{array}$} & \multirow[b]{2}{*}{ Operation } & \multicolumn{2}{|c|}{$\begin{array}{c}\text { Dia }=8.0 \mathrm{~mm}, \\
\text { Length=291 mm }\end{array}$} & \multicolumn{2}{|c|}{$\begin{array}{c}\text { Dia }=11.5 \mathrm{~mm} \text {, } \\
\text { Length=901 mm }\end{array}$} \\
\hline & & $\begin{array}{l}\text { Set } \\
\text { up } \\
(\text { min) }\end{array}$ & $\begin{array}{c}\text { Process } \\
\text { (min) }\end{array}$ & $\begin{array}{l}\text { Set up } \\
(\mathrm{min})\end{array}$ & $\begin{array}{c}\text { Process } \\
\text { (min) }\end{array}$ \\
\hline 1 & $\begin{array}{c}\text { Tube roll } \\
\text { length cutting }\end{array}$ & 0 & 0 & 0 & 2 \\
\hline 2 & $\begin{array}{l}\text { Lug length } \\
\text { cutting }\end{array}$ & & & 0 & 2 \\
\hline 3 & $\begin{array}{c}\text { Initial } \\
\text { straightening }\end{array}$ & 0 & 10 & 0 & 15 \\
\hline 4 & $\begin{array}{l}\text { Tube V } \\
\text { Grinding }\end{array}$ & 0.5 & 11.41 & 0.5 & 6.58 \\
\hline 5 & $\begin{array}{l}\text { Lug angle } \\
\text { matching }\end{array}$ & 0.6 & 9.16 & 0.83 & 7.30 \\
\hline 6 & Brazing & 0.41 & 5.16 & 1 & 5.47 \\
\hline 7 & OD roughing & 0.83 & 13.3 & 1 & 14.32 \\
\hline 8 & OD finishing & 0.66 & 10.53 & 1 & 13.17 \\
\hline 9 & Polishing & 0 & 0 & 0 & 2 \\
\hline 10 & $\begin{array}{l}\text { Top rake } \\
\text { roughing }\end{array}$ & 0.5 & 7.16 & 1 & 6.22 \\
\hline 11 & $\begin{array}{l}\text { Top rake } \\
\text { finishing }\end{array}$ & 0.5 & 6.25 & 0.83 & 5.63 \\
\hline 12 & Pad generation & 0.66 & 13.71 & 1 & 14.50 \\
\hline 13 & Face geometry & 0.83 & 16.78 & 1 & 17.13 \\
\hline 14 & $\begin{array}{l}\text { Shank reaming } \\
\text { and counter } \\
\text { boring }\end{array}$ & 0.66 & 3.13 & 0.5 & 6.67 \\
\hline 15 & Shank suiting & 0 & 4 & 0.25 & 4.17 \\
\hline 16 & Shank brazing & 0.5 & 5 & 0.33 & 6.5 \\
\hline 17 & Shank grinding & 0 & 0 & 1 & 5.38 \\
\hline 18 & Shank chamfer & 0 & 0 & 0.5 & 4 \\
\hline 19 & Entry chamfer & 0 & 2 & 0 & 2 \\
\hline 20 & $\begin{array}{l}\text { Final bend } \\
\text { removal }\end{array}$ & 0.16 & 12 & 0.17 & 15 \\
\hline 21 & $\begin{array}{l}\text { Oil flow } \\
\text { testing }\end{array}$ & 0.25 & 1 & 0.5 & 1 \\
\hline 22 & $\begin{array}{c}\text { Final } \\
\text { inspection }\end{array}$ & 0 & 4 & 0.08 & 2 \\
\hline \multirow{2}{*}{\multicolumn{2}{|c|}{$\begin{array}{l}\text { Total Manufacturing } \\
\text { Time }\end{array}$}} & 7.06 & 134.59 & 11.92 & 158.04 \\
\hline & & \multicolumn{2}{|c|}{141.65} & \multicolumn{2}{|c|}{169.95} \\
\hline
\end{tabular}


The cycle timings of grinding operations which is creating bottleneck are shown in Table 2. The setup time is considered only for initial setup, for analysis purpose only process time is considered which includes the stage inspection. Here the grinding of gundrill follows the same sequences for all different diameter gundrill. The main aim is to reduce the throughput time which is carried out in analysis part.

Table 2. Processing time for grinding operations

\begin{tabular}{|c|c|c|c|c|c|}
\hline \multirow[b]{2}{*}{$\begin{array}{r}\text { SI } \\
\text { No }\end{array}$} & \multirow[b]{2}{*}{ Operation } & \multicolumn{2}{|c|}{$\begin{array}{c}\text { Dia }=8.0 \mathrm{~mm}, \\
\text { Length=291 mm }\end{array}$} & \multicolumn{2}{|c|}{$\begin{array}{c}\text { Dia }=11.5 \mathrm{~mm}, \\
\text { Length }=901 \mathrm{~mm}\end{array}$} \\
\hline & & $\begin{array}{l}\text { Set } \\
\text { up } \\
\text { (min) }\end{array}$ & $\begin{array}{c}\text { Process } \\
\text { (min) }\end{array}$ & $\begin{array}{l}\text { Set up } \\
(\text { min) }\end{array}$ & $\begin{array}{c}\text { Process } \\
\text { (min) }\end{array}$ \\
\hline 1 & $\begin{array}{c}\text { OD } \\
\text { roughing }\end{array}$ & 0.83 & 13.3 & 1 & 14.32 \\
\hline 2 & $\begin{array}{c}\text { OD } \\
\text { finishing }\end{array}$ & 0.66 & 10.53 & 1 & 13.17 \\
\hline 3 & $\begin{array}{l}\text { Top rake } \\
\text { roughing }\end{array}$ & 0.5 & 7.16 & 1 & 6.22 \\
\hline 4 & $\begin{array}{l}\text { Top rake } \\
\text { finishing }\end{array}$ & 0.5 & 6.25 & 0.83 & 5.63 \\
\hline 5 & $\begin{array}{c}\text { Pad } \\
\text { generation }\end{array}$ & 0.66 & 13.71 & 1 & 14.50 \\
\hline 6 & $\begin{array}{c}\text { Face } \\
\text { geometry }\end{array}$ & 0.83 & 16.78 & 1 & 17.13 \\
\hline \multicolumn{2}{|c|}{ Manual grinding } & 3.98 & 67.73 & 5.83 & 70.97 \\
\hline \multirow{2}{*}{\multicolumn{2}{|c|}{$\begin{array}{l}\text { CNC grinding } \\
\text { Total time (min) }\end{array}$}} & 2 & 50 & 4 & 40 \\
\hline & & \multicolumn{2}{|c|}{71.71} & \multicolumn{2}{|c|}{76.80} \\
\hline
\end{tabular}

The reduction of cycle time for these operations is carried out in ARENA simulation software by Rockwell Automation Inc., for analysis purpose the area of interest will be the grinding operation which is shown in the Table 2. For simulation, gundrill having $8 \mathrm{~mm}$ diameter is taken. The reason is if run-out can be maintained in smaller diameter gundrill then it is easy to maintain all machining activities for higher diameter gundrill. For $8 \mathrm{~mm}$ diameter cycle timings are taken for a batch size of 25 numbers for grinding operations. ARENA provides built-in data analysis tool whose main objective is to fit distributions to a given sample. The distributions are analyzed for every grinding operation separately in the input analyzer tool. For OD roughing the histogram along with the distribution followed is shown in Figure 3.

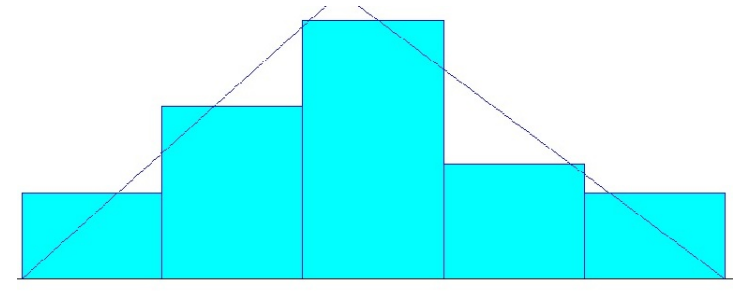

Figure 3. Distribution for OD roughing

The distribution followed here is triangular. The data can fit in all other distribution as well. But analyzer follows the best possible by least square error value. Expressions are generated along with the distributions which will be used to define the process in particular operation. Table 3 shows the distributions, expressions, and least square value which will be used while creating the simulation model.
Table 3. Distribution summary

\begin{tabular}{|c|c|c|c|}
\hline Operations & $\begin{array}{c}\text { Distribution } \\
\text { followed }\end{array}$ & Equation used & Error \\
\hline OD roughing & Triangular & TRIA(12.8,13.2,13.6) & 0.00738 \\
\hline OD finishing & Triangular & TRIA(10.2,10.6,10.8) & 0.01555 \\
\hline $\begin{array}{l}\text { Flute } \\
\text { roughing }\end{array}$ & Weibull & $5.31+\mathrm{WEIB}(0.81,5.14)$ & 0.04621 \\
\hline $\begin{array}{l}\text { Flute } \\
\text { finishing }\end{array}$ & Triangular & $\operatorname{TRIA}(5.73,6.17,6.36)$ & 0.01021 \\
\hline $\begin{array}{c}\text { Face } \\
\text { generation }\end{array}$ & Beta & $\begin{array}{c}16.6+0.44 \times B E T A \\
61)\end{array}$ & 0.029915 \\
\hline $\begin{array}{c}\text { Pad } \\
\text { generation }\end{array}$ & Beta & $\begin{array}{c}13.5+0.42 \mathrm{x} \\
\operatorname{BETA}(1.5,1.55)\end{array}$ & 0.011172 \\
\hline
\end{tabular}

After distribution analysis is completed a model is created in ARENA. The model is started with a basic process called create which is labeled as parts to be grinded followed by the individual process. The process is defined based on the delay type and expressions which are generated in input analyzer shown in Table 3. Allocation is defined as value added time because the non-value added time in the conventional method is very few seconds and it is negligible. Similarly every other operation is defined in the same way along with the decision block which is stage inspections which may be either roughness or diameter check. If it satisfies the condition it is carried moved to further processes. When the above model is simulated for batch size 25 and for ' $n$ ' replications the result of total average timing of all operations is shown in Figure 4. Since only value added time is considered, non-value added time, wait time, transfer times are zero for the reason that all other times are negligible during the process. To find the average cycle timings of each individual process model is created to each single process similarly using the expressions and procedures and simulation is carried out and results are tabulated in Table 4.

\begin{tabular}{|c|c|c|c|c|}
\hline VA Time & Average & Half Width & Minimum & Maximum \\
\hline Entity 1 & 74.7112 & (Insufficient) & 65.8781 & 107.85 \\
\hline NVA Time & Average & Half Width & Minimum & Maximum \\
\hline Entity 1 & 0 & (Insufficient) & 0 & 0 \\
\hline Wait Time & Average & Half Width & Minimum & Maximum \\
\hline Entity 1 & 0 & (Insufficient) & 0 & 0 \\
\hline Transfer Time & Average & Half Width & Minimum & Maximum \\
\hline Entity 1 & 0 & (Insufficient) & 0 & 0 \\
\hline Other Time & Average & Half Width & Minimum & Maximum \\
\hline Entity 1 & 0 & (Insufficient) & 0 & 0 \\
\hline Total Time & Average & Half Width & Minimum & Maximum \\
\hline Entity 1 & 74.7112 & (Insufficient) & 65.8781 & 107.85 \\
\hline \multicolumn{5}{|l|}{ Other } \\
\hline Number in & Value & & & \\
\hline Entity 1 & 25 & & & \\
\hline Number Out & Value & & & \\
\hline Entity 1 & 25 & & & \\
\hline$\underline{W I P}$ & Average & Half Width & Minimum & Maximum \\
\hline Entity 1 & 2.8165 & (Insufficient) & 0 & 6.0000 \\
\hline
\end{tabular}

Figure 4. Simulation result for conventional model 
Table 4. Average cycle timings for grinding operations by ARENA

\begin{tabular}{ccc}
\hline SI No & Operations & Avg. Time (mins) \\
\hline 1 & OD roughing & 14.66 \\
2 & OD finishing & 11.61 \\
3 & Flute roughing & 6.71 \\
4 & Flute finishing & 6.76 \\
5 & Face generation & 18.67 \\
6 & Pad generation & 15.37 \\
& Total & 73.78 \\
\hline
\end{tabular}

\subsection{Validating ARENA model}

To find whether the ARENA model resembles the conventional method, a non-parametric test is done by checking null hypothesis and checking p-value. Usually nonparametric test is done when the data is assumed to be not following the normal distribution. For non-parametric test Wilcoxon signed rank test is carried out for two samples. It is a non-parametric statistical hypothesis test used to compare two related samples, matched samples, or repeated measurements when the population cannot be assumed to be normally distributed. For the test average timings from individual operations from shop floor and average individual results of simulation model is taken. Null hypothesis test is conducted with $5 \%$ significance level and p-value is calculated. The Wilcoxon signed rank test for two samples is carried out in mini- tab and results are shown in Figure 5.

\section{3/04/2015 12:46:48}

Welcome to Minitab, press F1 for help.

Wilcoxon Signed Rank Test: C3

Test of median $=0.000000$ versus median $\neq 0.000000$

\begin{tabular}{|c|c|c|c|c|}
\hline & $N$ for & Wilcoxon & & timated \\
\hline $\mathbb{N}$ & Test & Statistic & P & Median \\
\hline 6 & 6 & 18.0 & 0.142 & 0.6650 \\
\hline
\end{tabular}

Figure 5. Wilcoxon signed rank test for null hypothesis

The $p$-value is greater than the significance value i.e. $p>0.05$ which shows the weak evidence against the null hypothesis, so fails to reject the null hypothesis. This proves the median of ARENA timings and median of manual reading are equal. This further justifies the resemblance between ARENA model and manual readings from shop floor.

\subsection{ARENA for CNC}

For the special purpose $\mathrm{CNC}$ machine since there is no data for finding distributions and run a model in ARENA alternate way of assuming distributions is done. When distributions are not known triangular distributions is commonly used in these circumstances. It estimates for the minimum, maximum and most likely values available. The triangular distributions are easier to use and explain than other distributions and may be used in this situation [6]. The minimum, maximum and most likely values are taken from the timings which is taken from floor is used to define the process for CNC and another model is created similarly to the manual ARENA model as shown in Figure 6 .

Here the procedure for model creation goes same except while defining the process instead of expression every process is assumed to be following the triangular distribution and minimum, maximum and most likely value is given as input. Since it is a CNC grinding machine no stage inspections are involved as in manual method, when simulated results are generated as shown in Figure 7. The total cycle timing which is given by ARENA is following the same condition as in manual process i.e. feed rate, depth of cut and all other grinding parameters. The cut-off timings for all grinding operations are shown in Table 5.

For the same ARENA model in Figure 6, for all cycle timings having maximum, minimum and the mode (most likely value) the values are reduced a value of $75 \%$ for all operation and model is simulated the average final value is shown in Figure 8. The cut-off timings for all individual operations are shown in Table 6 . Here the total cycle timing is reduced to 16.44 mins. This reduced cycle times means the main machining parameters like feed-rate and depth of cut considered here for conventional as well as for proposed $\mathrm{CNC}$ when increased by certain percentages the cycle timings can be reduced and the target can be achieved.

Table 7 shows the comparison of the results obtained from manual, ARENA and CNC methods.

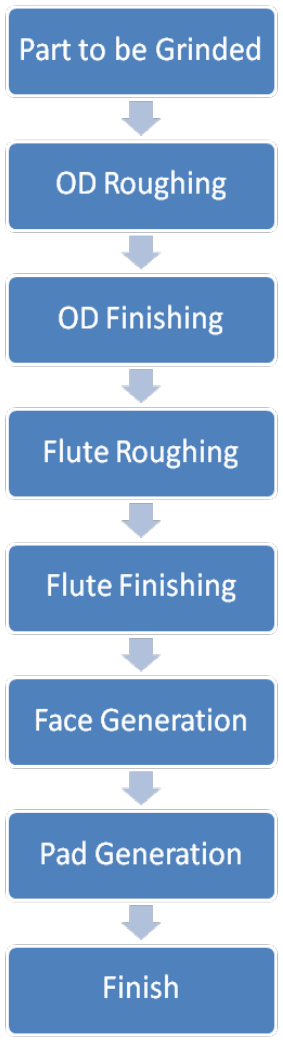

Figure 6. Simulation model for $\mathrm{CNC}$

Table 5. Average cycle timings for $\mathrm{CNC}$

\begin{tabular}{ccc}
\hline SI No & Operations & Avg. Time (mins) \\
\hline 1 & OD roughing & 13.22 \\
2 & OD finishing & 10.5 \\
3 & Flute roughing & 5.94 \\
4 & Flute finishing & 6.05 \\
5 & Face generation & 16.79 \\
6 & Pad generation & 13.67 \\
\hline
\end{tabular}




\begin{tabular}{|c|c|c|c|c|c|c|}
\hline VA Time & Average & HalfWich & $\begin{array}{l}\text { Whinum } \\
\text { Alverzye }\end{array}$ & $\begin{array}{l}\text { Maximun } \\
\text { Average }\end{array}$ & $\begin{array}{l}\text { Whinum } \\
\text { Value }\end{array}$ & $\begin{array}{l}\text { Maximun } \\
\text { Valua }\end{array}$ \\
\hline Enty1 & 662011 & 0.02 & 66.0974 & 66.3399 & 65.3445 & 66.9927 \\
\hline NVA Tine & Average & Halflich & $\begin{array}{l}\text { llinimum } \\
\text { Alvasye }\end{array}$ & $\begin{array}{l}\text { Maximum } \\
\text { Avergege }\end{array}$ & $\begin{array}{l}\text { Winimum } \\
\text { Value }\end{array}$ & $\begin{array}{l}\text { Maximyn } \\
\text { Vabua }\end{array}$ \\
\hline Entity1 & 0.00 & 0.00 & 0.00 & 0.00 & 0.00 & 0.00 \\
\hline Wait Time & Average & Halflich & $\begin{array}{l}\text { Minimum } \\
\text { Aveazye }\end{array}$ & $\begin{array}{l}\text { Usimmun } \\
\text { Avergage }\end{array}$ & $\begin{array}{l}\text { Mininum } \\
\text { Value }\end{array}$ & $\begin{array}{l}\text { Maxinyn } \\
\text { Valus }\end{array}$ \\
\hline Enty1 & 0.00 & 0.00 & 0.00 & 0.00 & 0.00 & 0.00 \\
\hline Transere Time & Average? & HalfWith & $\begin{array}{l}\text { llinimum } \\
\text { Alveagye }\end{array}$ & $\begin{array}{l}\text { Maximum } \\
\text { Average }\end{array}$ & $\begin{array}{l}\text { Mrinum } \\
\text { Value }\end{array}$ & $\begin{array}{l}\text { Maximun } \\
\text { Valua }\end{array}$ \\
\hline Enty1 & 0.00 & 0.00 & 0.00 & 0.00 & 0.00 & 0.00 \\
\hline Oher Tme & Average: & Hallwith & $\begin{array}{l}\text { Ninimum } \\
\text { Aleraye }\end{array}$ & $\begin{array}{l}\text { Usimun } \\
\text { Avergeg }\end{array}$ & $\begin{array}{l}\text { Mrinum } \\
\text { Value }\end{array}$ & $\begin{array}{l}\text { Maximum } \\
\text { Valua }\end{array}$ \\
\hline Entty1 & 0.00 & 0.00 & 0.00 & 0.00 & 0.00 & 0.00 \\
\hline Total Time & Average & Half(Widh & $\begin{array}{l}\text { llinimum } \\
\text { Alveages }\end{array}$ & $\begin{array}{l}\text { Maximun } \\
\text { Averegge }\end{array}$ & $\begin{array}{l}\text { Wininum } \\
\text { Valle }\end{array}$ & $\begin{array}{l}\text { Maximum } \\
\text { Valua }\end{array}$ \\
\hline $\begin{array}{l}\text { Entity1 } \\
\text { Other" }\end{array}$ & 662011 & 0.02 & 66.0974 & 66.3399 & 65.3455 & 66.9927 \\
\hline Number In & Averigg: & Halflich & $\begin{array}{l}\text { Whinimum } \\
\text { Alveagye }\end{array}$ & $\begin{array}{l}\text { Maximum } \\
\text { Avergege }\end{array}$ & & \\
\hline Enty1 & 25.0000 & 0.00 & 2500000 & 25.0000 & & \\
\hline
\end{tabular}

Figure 7. Simulation results for $\mathrm{CNC}$ model

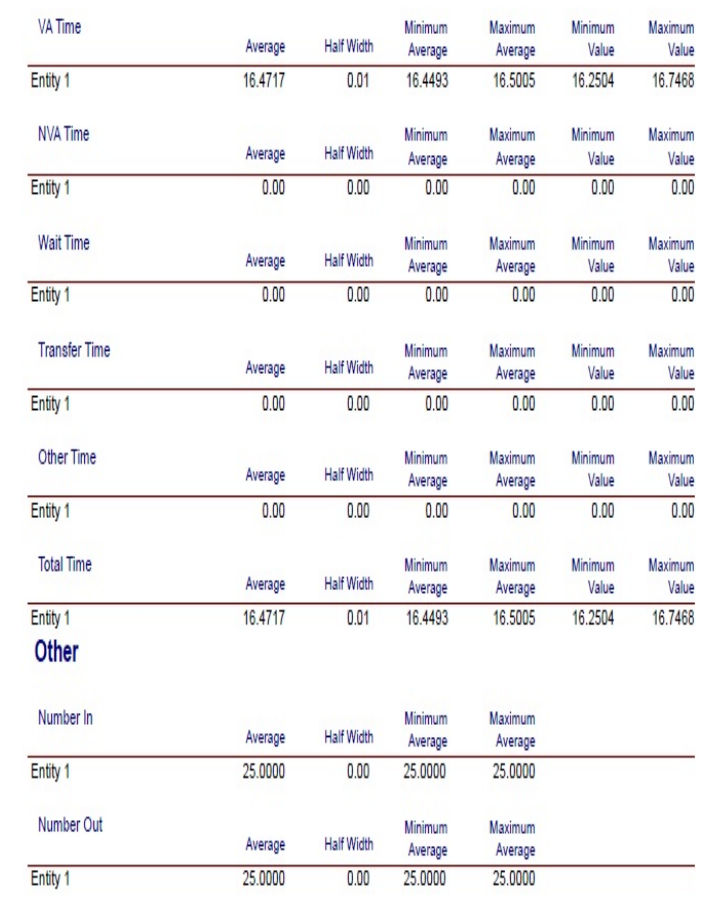

Figure 8. Cycle timings for $75 \%$ reduction

Table 6. Cycle timings of individual operation for CNC $75 \%$ reduction

\begin{tabular}{ccc}
\hline SI No & Operations & Avg. Time (mins) \\
\hline 1 & OD roughing & 3.29 \\
2 & OD finishing & 2.6 \\
3 & Flute roughing & 1.47 \\
4 & Flute finishing & 1.5 \\
5 & Face generation & 4.18 \\
6 & Pad generation & 3.4 \\
\hline
\end{tabular}

Table 7. Comparison of results

\begin{tabular}{ccccc}
\hline Operations & $\begin{array}{c}\text { Manual } \\
\text { (mins) }\end{array}$ & $\begin{array}{c}\text { Manual } \\
\text { ARENA } \\
\text { (mins) }\end{array}$ & $\begin{array}{c}\text { ARENA } \\
\text { for CNC } \\
\text { (mins) }\end{array}$ & $\begin{array}{c}\text { CNC } \\
\mathbf{7 5} \text { (mins) }\end{array}$ \\
\hline OD roughing & 13.3 & 14.66 & 13.22 & 3.29 \\
$\begin{array}{c}\text { OD finishing } \\
\text { Flute }\end{array}$ & 10.53 & 11.61 & 10.5 & 2.6 \\
roughing \\
$\begin{array}{c}\text { Flute } \\
\text { finishing } \\
\text { Face }\end{array}$ & 7.16 & 6.71 & 5.94 & 1.47 \\
$\begin{array}{c}\text { generation } \\
\text { Pad }\end{array}$ & 16.78 & 18.67 & 16.79 & 4.18 \\
generation & 13.71 & 15.37 & 13.67 & 3.4 \\
\hline Total & 67.73 & 73.78 & 66.17 & 16.44 \\
\hline
\end{tabular}

\section{CONCLUSIONS}

The average cycle timings for manual and average readings from ARENA are tabulated above. By reducing the cycle timings by $75 \%$ in which the defined values are assumed to follow the triangular distribution. This paper presented the problems faced during gundrill manufacturing, and the best possible way to reduce the cycle time of operations and to reduce total throughput time would be to installing a special purpose $\mathrm{CNC}$ grinding machine for grinding operations which are carried out on the carbide lug which also reduces the stage inspections, setup times, move time, queue time and also the cycle time of operations. In this project the main aim was to reduce the cycle time of the operations which were creating bottleneck which was responsible for reduction in total throughput time and productivity. By using ARENA as a tool, simulation was carried out for both conventional and also for special purpose CNC. Non- parametric test is conducted to find the resemblance between the model and cycle time collected by checking null-hypothesis and finding $\mathrm{p}$-value. By reducing the cycle timings which are assumed to be following triangular distributions and by lowering certain percentages, cycle timings are reduced. The same procedure can be carried out for various single lip gundrills and twin lip gundrill and based on the results obtained the machining parameters can be changed to improve productivity. By installing a $\mathrm{CNC}$ grinding machine to these operations reduces the tedious job to the operator and can expect better quality of component without effecting quality of tool and by also to follow better EHS practice.

\section{REFERENCES}

[1] Zhu, L., Geng, Y. (2014). The design of gun-drill sharpening device. Applied Mechanics and Materials, 618: 439-442. http://www.scientific.net/AMM.618.439

[2] Beju, L.D., Brindasu, D.P., Vulc, S., (2015). Grinding tungsten carbide used for manufacturing gun drills. Journal of Mechanical Engineering, 61: 571-582. http://dx.doi.org/10.5545/sv-jme.2015.2594

[3] Wang, Y., Jia, W., Zhang, J. (2014). The force system and performance of the welding carbide gun drill to cut AISI 1045 steel. The International Journal of Advanced Manufacturing Technology, 74: 1431-1443. http://dx.doi.org/10.1007/s00170-014-6072-4

[4] Biermann, D., Kirschner, M. (2015). Experimental 
investigations on single-lip deep hole drilling of superalloy Inconel 718 with small diameters. Journal of Manufacturing Processes, 20: 332-339. http://dx.doi.org/10.1016/j.jmapro.2015.06.001

[5] Puneet, C., Valleti, K., Gopal, A.V. (2017). Influence of surface preparation on the tool life of cathodic arc PVD coated twist drills. Journal of Manufacturing Processes, 27: 233-240. https://doi.org/10.1016/j.jmapro.2017.05. 011

[6] Chen, T. (2013). A systematic cycle time reduction procedure for enhancing the competitiveness and sustainability of a semiconductor manufacturer. Sustainability, 5(11): 4637-4652. http://dx.doi.org/10.3390/su5114637

[7] Koltai, T., Kalló, N., Györkös, R. (2015). Calculation of the throughput-time in simple assembly lines with learning effect. IFAC-PapersOnLine, 48(3): 314-319. http://dx.doi.org/10.1016/j.ifacol.2015.06.100

[8] Koltai, T., Kalló, N. (2017). Analysis of the effect of learning on the throughput-time in simple assembly lines. Computers \& Industrial Engineering, 111: 507-515. http://dx.doi.org/10.1016/j.cie.2017.03.034

[9] Mansouri, S.A., Golmohammadi, D., Miller, J. (2019). The moderating role of master production scheduling method on throughput in job shop systems. International Journal of Production Economics, 216: 67-80. http://dx.doi.org/10.1016/j.ijpe.2019.04.018

[10] Turpin, L. (2018). A note on understanding cycle time. Journal of Production Economics, 205: 113-117. http://dx.doi.org/10.1016/j.ijpe.2018.09.004

[11] Mohan, R.R., Kumar, S. (2013). A throughput time study on gemba through $\mathrm{ABC}$ analysis for high demand product among varieties of products. IOSR Journal of Mechanical and Civil Engineering, 5(1): 57-59. http://dx.doi.org/10.9790/1684-0515759

[12] Johnson, D.J. (2003). A framework for reducing manufacturing throughput time. Journal of Manufacturing Systems, 22(4): 283-298. http://dx.doi.org/10.1016/S0278-6125(03)80009-2

[13] Far, H., Haleh, H., Saghaei, A. (2018). A flexible cell scheduling problem with automated guided vehicles and robots under energy-conscious policy. Scientia Iranica, 25: 339-358. http://dx.doi.org/10.24200/sci.2017.4399

[14] Chincholkar, M., Herrmann, J.W. (2008). Estimating manufacturing cycle time and throughput in flow shops with process drift and inspection. International Journal of Production Research, 46(24): 7057-7072. http://dx.doi.org/10.1080/00207540701513893

[15]. Herrmann, J.W., Chincholkar, M.M. (2002). Reducing throughput time during product design. Journal of Manufacturing Systems, 20(6): 416-428. http://dx.doi.org/10.1016/S0278-6125(01)80061-3 